\title{
ALBEDO MEASUREMENTS OF AN ARGTIC ICE COVER FROM HIGH TOWERS
}

\author{
By M. P. Langleben \\ (Ice Research Project, Department of Physics, McGill University, Montreal, Canada)
}

\begin{abstract}
Radiometers, suspended at a height of $15 \mathrm{~m}$ between two towers anchored to the bottom of the ice cover, have been used to measure the average or integrated albedo of the surface. The work was carried out in May 1967 at Tanquary Fiord, Ellesmere Island (lat. $81^{\circ} 25^{\prime}$ N., long. $76^{\circ} 50^{\prime}$ W.) during the period when the surface of the ice cover was undergoing rapid change. The albedo was observed to have a value of almost 1.o, for a fresh snow cover, and about 0.8 for a weathered snow cover. It decreased to o. 6 as the wind partially cleared the surface of snow and gradually to 0.5 with further deterioration of the snow. The onset of melting, produced when the daily mean temperature exceeded $o^{\circ} \mathrm{C}$, rapidly lowered the albedo to a value of about 0.3 .
\end{abstract}

Résumé. Mesures d'albedo de couverture de glace arctique à partir de hautes tours. Des radiomètres, suspendus à une hauteur de $15 \mathrm{~m}$ entre deux tours ancrées au fond d'une couverture de glace, ont été utilisés pour mesurer l'albedo moyenne ou intégrée de la surface. Ce travail a été réalisé en mai $19^{5} 7$ à Tanquary Fiord, île d'Ellesmere $\left(81^{\circ} 25^{\prime} \mathrm{N}, 76^{\circ} 50^{\prime} \mathrm{W}\right)$ pendant la période où la surface est soumise à un rapide changement.

Il a été observé que l'albedo diminue environ de $\mathrm{I}, \mathrm{o}$ pour une couverture de neige fraîche, à environ o,8 pour une couverture de neige plus vieille. Elle se réduit à o,6 lorsque le vent a partiellement nettoyé la surface, et graduellement à 0,5 avec la détérioration ultérieure de la neige. L'apparition de la fonte, produite lorsque la température moyenne diurne dépasse $0^{\circ} \mathrm{C}$, abaisse rapidement l'albedo à une valeur d'environ 0,3 .

Zusammenfassung. Albedo-Messungen einer arktischen Eisdecke von hohen Türmen. Zur messung der mittleren oder totalen Albedo einer Eisdecke wurden Radiometer verwendet, die in einer Höhe von $15 \mathrm{~m}$ zwischen zwei im Eise verankerten Türmen aufgehängt waren. Die Arbeit wurde im Mai 1967 im Tanquary Fiord auf der Ellesmere-Insel $\left(81^{\circ} 25^{\prime} \mathrm{N}, 76^{\circ} 5^{\prime} \mathrm{W}\right)$ während der Periode schnellen Wechsels auf der Oberfläche der Eisdecke ausgeführt.

Die Beobachtung ergab eine Abnahme der Albedo von fast 1,o für eine frische Schneedecke auf ca. o,8 unter dem Einfluss des Wetters. Sie sank auf 0,6 , als der Wind die Oberfläche teilweise schneefrei fegte, und weiter auf o, 5 mit weiterem Abbau des Schnees. Das Einsetzens des Schmelzens, das bei mittleren Tagestemperaturen von über $0^{\circ} \mathrm{C}$ zustande kam, senkte die Albedo schnell auf einen Wert von etwa 0,3 .

\section{INTRODUGTION}

Knowledge of the albedo of the ice cover in the Arctic Ocean, at the beginning and during the melt season, is of great importance in energy budget studies of the Arctic Basin. With the sun above the horizon continuously and with increasing solar angle, large values of daily total incident short-wave radiation are expected. (Langleben (1966) reports values of about $800 \mathrm{cal} \mathrm{cm} \mathrm{cm}^{-2} \mathrm{~d}^{-1}$ in May at lat. $8 \mathrm{I}^{\circ} 25^{\prime} \mathrm{N}$., long. $76^{\circ} 5^{\mathrm{o}^{\prime} \mathrm{W}}$.) Since the albedo determines the quantity of solar radiation absorbed by the ice cover, even small changes in its value can greatly influence the amount of surface ablation by melting when the incident radiation is high.

Values of albedo during the melt season are quoted by Marshunova (i 96r), Chernigovskiy ( 1963 ) and Langleben (1966). These are obtained from measurements typically made with two short-wave radiometers mounted back-to-back at a height of one to two metres above the surface. The ratio of the response of the downward to upward facing instrument is taken to represent the albedo of the surface. For the downward facing instrument, as will be shown, $5^{\circ}$ per cent of its response arises from reflections at the surface from an area of radius equal to the height above ground of the radiometer, and about go per cent from an area of radius equal to three times the height. The contributing area of surface for radiometer heights normally used is thus of radius several metres.

During the melt season, the ice cover assumes non-uniform surface features which also have dimensions of several metres. It is possible that a melt pond develops below the instrumentation, or a white hummock. It is obvious that measurements of reflected radiation (and of albedo) would differ radically in the two cases. Some such effect may explain discrepancies in values of albedo of sea ice during the melt season, reported by Marshunova (I96I) as about 0.2 for coastal areas, by Langleben ( 1966 ) as about 0.2 in a fiord and by Chernigovskiy (1963) 
as about 0.45 for the drifting stations. Measurements from a small number of such sites form the basis for calculations used to determine the energy budget of the Arctic Basin (Vowinckel and Orvig, I964; Fletcher, I 965). An estimate of the average albedo of the surface from point measurements would require a detailed knowledge of the relative proportion of wet to dry areas of the ice cover.

It is possible to avoid the necessity of making estimates of average albedo from point measurements over hummocks and melt ponds. Measurements representative of the surface can be made from a low flying aircraft if proper care is taken to maintain constant attitude, or from a tethered balloon if allowance can be made for the reduction of incoming radiation because of screening by the balloon.

The measurements discussed in this paper were obtained from instruments suspended at an altitude of $5^{\circ} \mathrm{ft}(\approx \mathrm{I} 5 \mathrm{~m})$ midway between two $6 \mathrm{o}-\mathrm{ft}(\approx \mathrm{I} 8-\mathrm{m})$ towers placed $\mathrm{Ioo} \mathrm{ft}(\approx 30 \mathrm{~m})$ apart. This method affords the opportunity of continuous study of an extensive area as the surface properties of the ice cover undergo the seasonal change. The work was carried out in Tanquary Fiord, Ellesmere Island (lat. $8 \mathrm{I}^{\circ} 25^{\prime}$ N., long. $76^{\circ} 5 \mathrm{o}^{\prime} \mathrm{W}$.) on second-year ice of thickness about $2.5 \mathrm{~m}$.

\section{THEORY}

Total hemispherical radiometers theoretically have an acceptance solid angle of $2 \pi$ steradians from a cone of half-angle $\pi / 2$ radians. Practically however the downward facing radiometer, looking at a horizontal surface, effectively gathers its response from a relatively small area which is closest to it. An appreciation of this fact emerges from the following considerations.

Assume that solar radiation reflected by the horizontal ice cover is perfectly diffuse and of radiant density $\mu$. Consider (Fig. I) an annular ring in the surface where the annulus has a radius $\rho=\mathrm{OQ}$, a width $\mathrm{d} \rho$ and an area $\mathrm{d} A=2 \pi \rho \mathrm{d} \rho$. Let $\mathrm{P}$ be a point vertically displaced from o through a height $z$; let $r$ be the distance from any point $Q$ on the annulus to $\mathrm{P}$; and let $\theta$ be the angle between oP and $P Q$, i.e. the half-angle with the vertical.

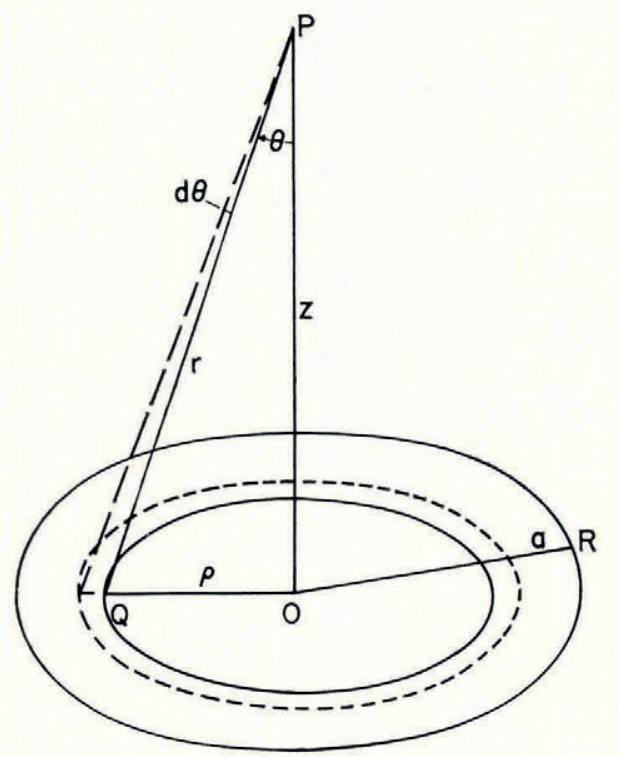

Fig. I. A schematic diagram of the geometry referred to in the theory 
If $\mathrm{d} I$ is the contribution to the intensity of radiation at $\mathrm{P}$ arising from reflections from the annular ring, then

$$
\mathrm{d} I=\frac{\mu \mathrm{d} A}{r^{2}} \cos \theta
$$

where the factor $\cos \theta$ accounts for the fact that flux in the off-normal direction is being considered.

It follows that the element of flux intercepted by a horizontal sensor of area $S$ at the point $\mathrm{P}$ is then

$$
\mathrm{d} E=S \cos \theta \mathrm{d} I
$$

where $S \cos \theta$ is the projected area of the sensor in a direction normal to the radiation from the annulus.

Now $r=z \sec \theta$ and $\rho=z \tan \theta$ and therefore

$$
\mathrm{d} E=2 \pi \mu S \sin \theta \cos \theta \mathrm{d} \theta .
$$

The flux intercepted by the sensor at $\mathrm{P}$ from a circular disc which subtends a half-angle at $\mathrm{P}$ of $\theta_{0}=\tan ^{-1} a / z$, where $a=$ OR is the radius of the disc, is

$$
\begin{aligned}
E\left(\theta_{0}\right) & =2 \pi \mu S \int_{0}^{\theta_{0}} \sin \theta \cos \theta \mathrm{d} \theta \\
& =\pi \mu S \sin ^{2} \theta_{0} .
\end{aligned}
$$

The total flux intercepted, i.e. the flux from an infinite sheet, is obtained by letting $a \rightarrow \infty$, i.e. $\theta_{0} \rightarrow \pi / 2$, whence

$$
E\left(90^{\circ}\right)=\pi \mu S
$$

and the fraction of the total flux, coming from the base of a cone of half-angle $\theta_{0}$, is

$$
\frac{E\left(\theta_{0}\right)}{E\left(90^{\circ}\right)}=\sin ^{2} \theta_{0}
$$

The function $\sin ^{2} \theta_{0}$ is plotted in Figure 2 against the ratio $a / z=\tan \theta_{0}$ as abscissa. It is seen that the percentage of total reflected radiation contributed by a circular patch of surface

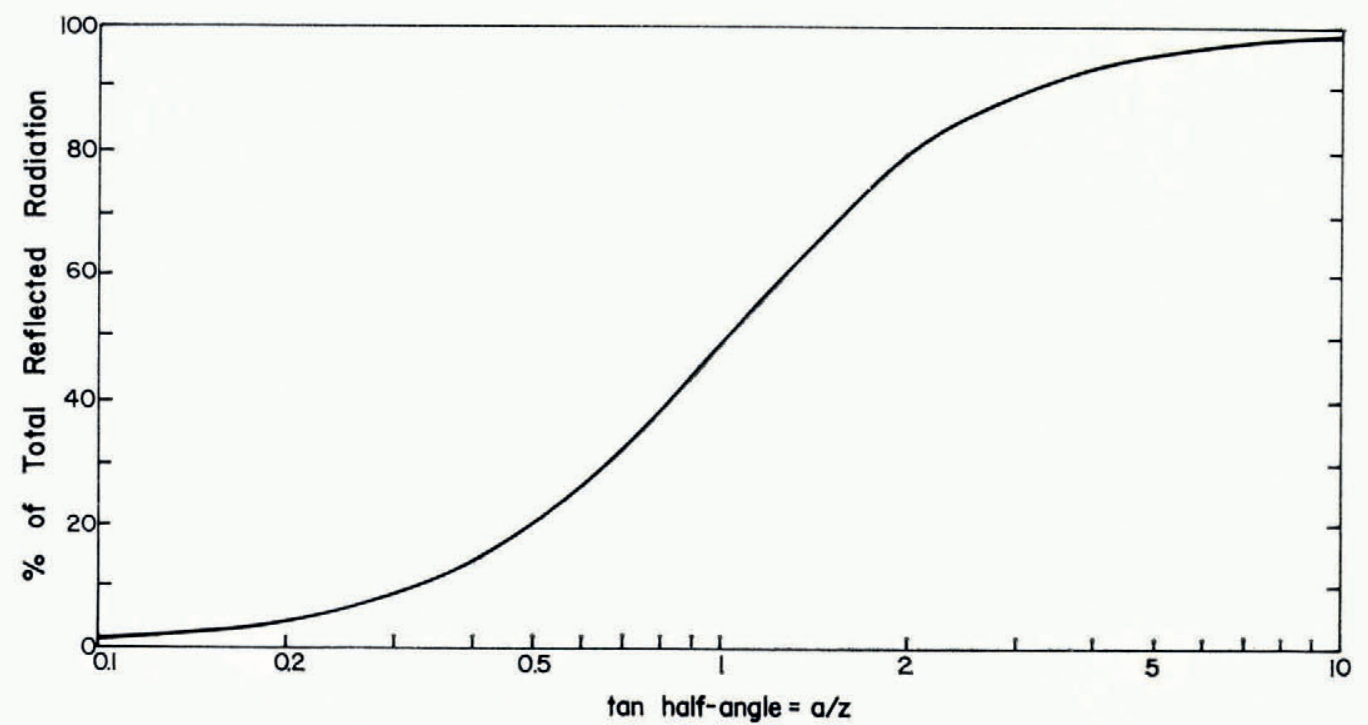

Fig. 2. The percentage of the total reflected radiation which comes from the base of a cone of half-angle at the radiometer $=\tan ^{-1} a / z$ where $a$ is the radius of the base and $z$ the height, is shown as a function of $a / z$ 
beneath the radiometer depends on the ratio of the radius of the patch to the height of the radiometer above the surface. The percentage is 50 for a ratio of radius to height of $\mathrm{I}, 8 \mathrm{o}$ when the ratio is 2 , and almost 90 when the ratio is 3 . Thus virtually all ( $\approx 90$ per cent) of the reflected radiation reaches the radiometer from an area of radius only three times the height of radiometer.

Radiometers typically are mounted at the standard meteorological height, about $\mathrm{I} .5 \mathrm{~m}$. For such cases, the sampling area of the surface is effectively of radius $4.5 \mathrm{~m}$, a dimension comparable to the size of a melt pond or a hummock. Hence the value of reflected radiation is extremely sensitive to the location of the radiometer.

To overcome this shortcoming, it is necessary to increase the height of the radiometer above the surface. Our instrument was at a height of approximately $15 \mathrm{~m}$ so that the effective sampling area was of radius $45 \mathrm{~m}$. A surface area of this size is large enough to contain tens of ponds and hummocks during the melt period. The detector samples radiation reflected from many ponds and hummocks and produces an integrated value for the albedo typical of the general surface rather than particular features of it.

\section{EXPERIMENTAL}

\section{(a) Tower construction}

Two towers of $18 \mathrm{~m}$ length were assembled in a horizontal attitude from smaller sections and then raised to the vertical at a distance of $30 \mathrm{~m}$ apart. Various stages during the erection are shown in Figures 3 to 6 . The base of each tower rested on a wooden platform, secured to the ice to prevent lateral movement. Stability was achieved by anchoring the towers with guy wires which were fastened to pieces of lumber resting against the underside of the ice cover.

Wires, running over fixed pulleys at the top of each tower, were provided for attachment to the instrumentation (Fig. 5). The wires were pulled in until the downward-facing radiometer was at a height of $50 \mathrm{ft}(\mathrm{I} 5 \mathrm{~m})$. The towers were oriented in a direction perpendicular to the prevailing winds.

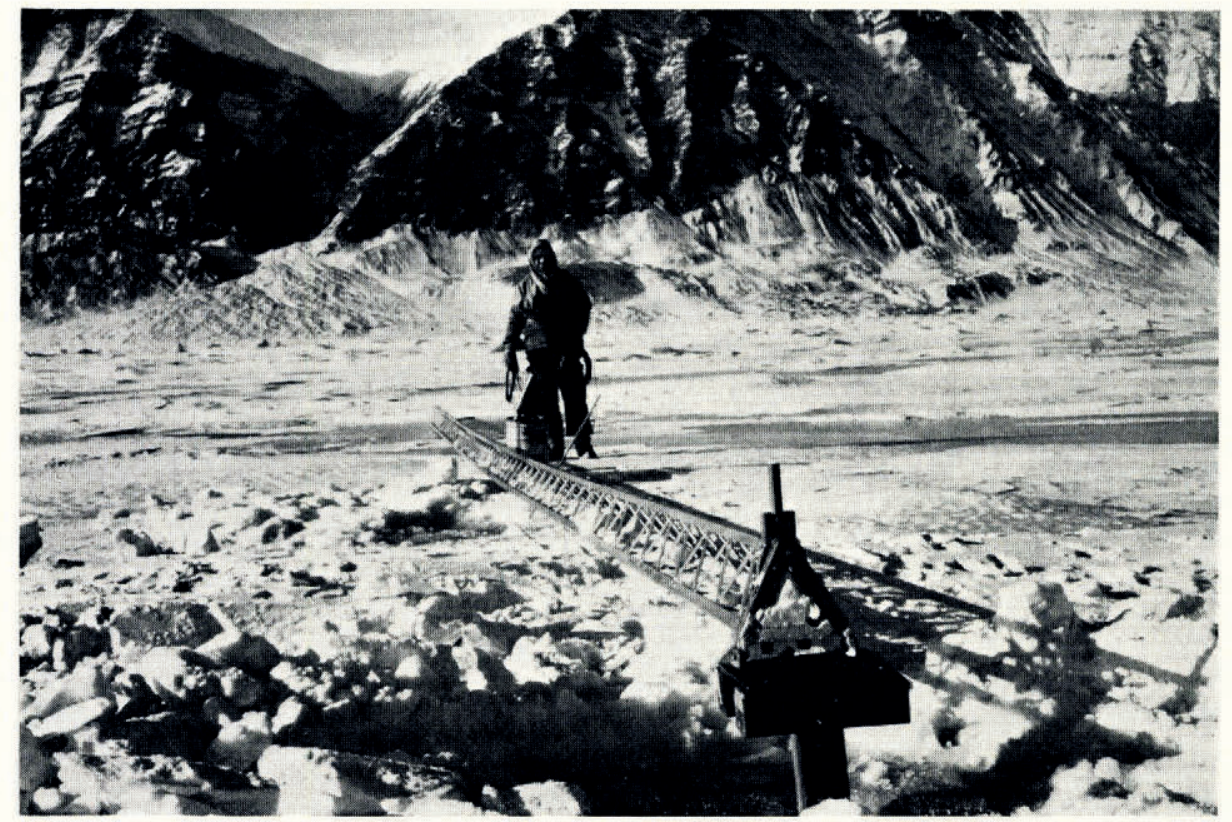

Fig. 3. Tower in horizontal position with wood platform for its base in foreground. The vertical projection is for attachment of a jib pole used to erect the tower. The mountains in the background are more than $5 \mathrm{~km}$ away 


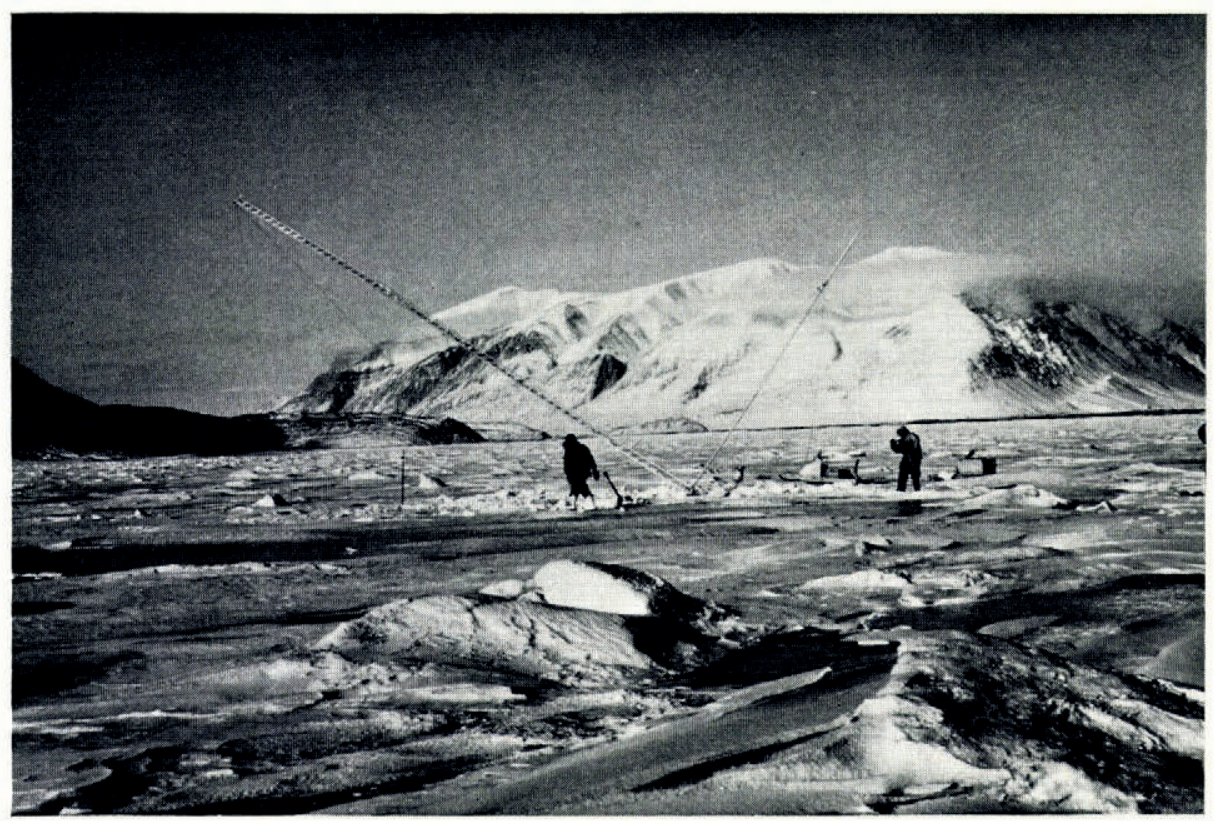

Fig. 4. Tower in process of erection. The use of the jib pole is clearly seen

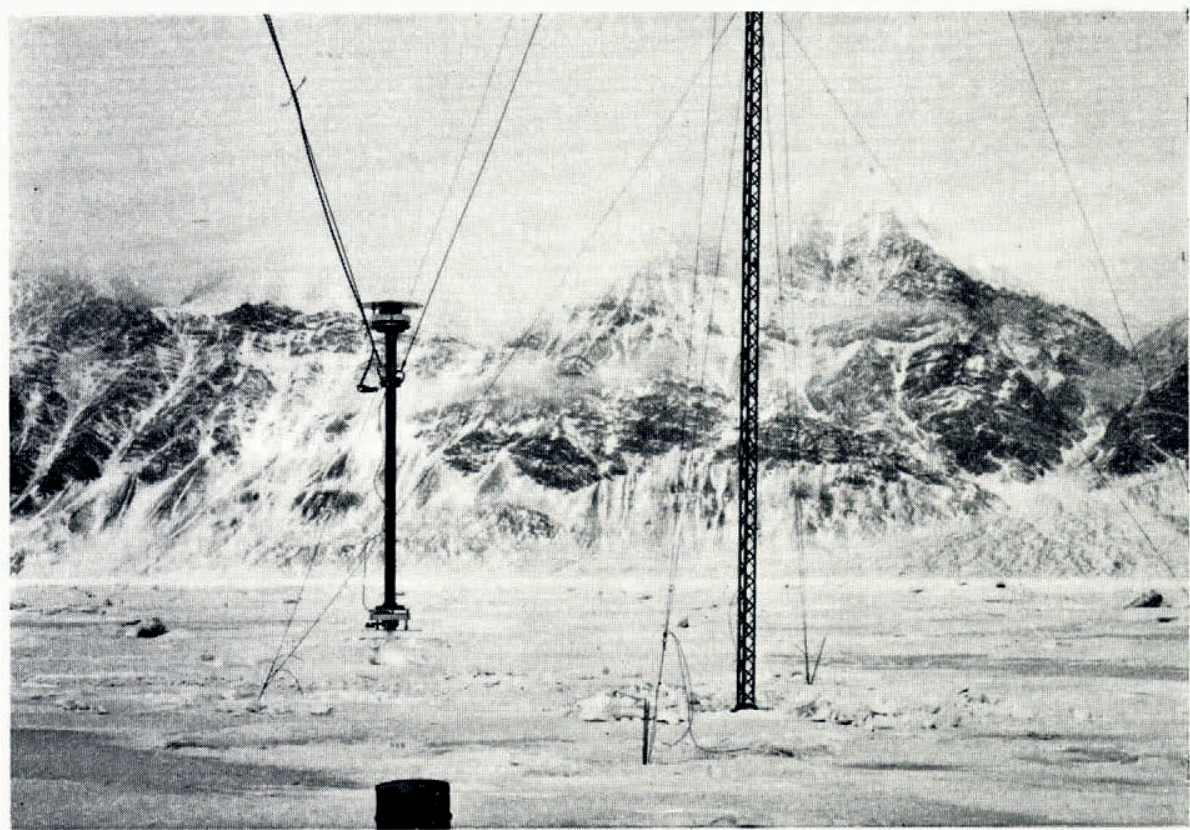

Fig. 5. The radiometers at each end of the pendulum-like mounting before being raised. The system of guy and anchor wires for the tower is also visible 


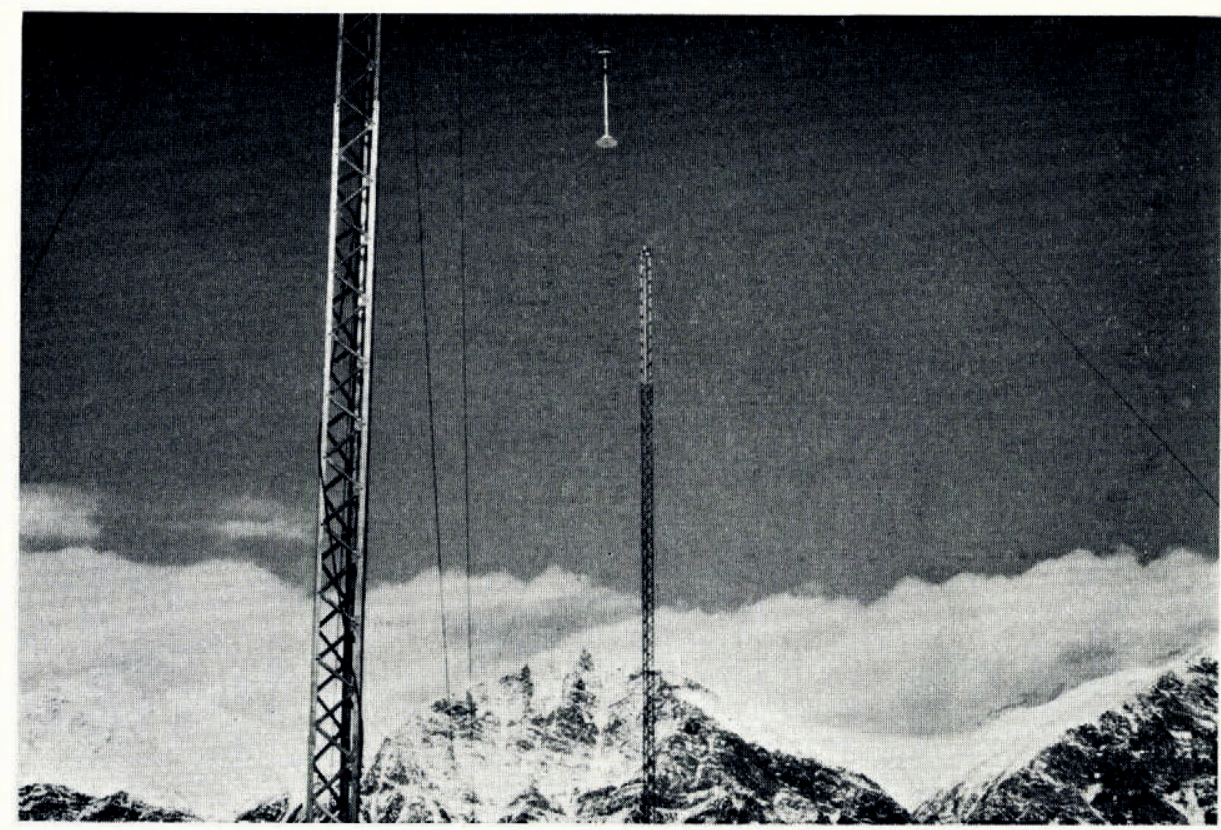

Fig. 6. The instrumentation suspended between the two towers

\section{(b) Instrumentation}

The radiometers and assembly can be seen in Figure 5. The radiometers were secured to flanges at the ends of a $1.5 \mathrm{~m}$ aluminium pipe. Each instrument was levelled with the assembly hanging freely from the support cables and the assembly was then drawn up to observation height. The assembly was free to pivot in a gimbal mount which was attached to the support cables. This type of mount proved very satisfactory. Pendulum-like swinging was indiscernible, even in stormy conditions. In strong winds, it was observed that the whole assembly moved laterally but with no noticeable inclination to the vertical.

The instruments used were the Kipp short-wave hemispherical radiometers. They had been calibrated by the Meteorological Branch, Department of Transport. (The calibration procedure consisted of placing the radiometers next to a laboratory standard on a rotating table at the centre of a $2 \mathrm{~m}$-diameter integrating sphere where the isotropic radiant intensity was I.2 $\mathrm{cal} \mathrm{cm}^{-2} \mathrm{~min}^{-1}$, and comparing the e.m.f.'s to that of the standard. The radiometers were also run outdoors in parallel with a secondary standard.) The outputs of the radiometers were recorded automatically on a multipoint d.c. millivoltmeter of recycling time of $6 \mathrm{~min}$ which was kept in a closed container attached to the base of one of the towers.

\section{Observations and Results}

\section{(a) The ice cover}

The investigation was carried out on second-year ice which covered the head of Tanquary Fiord in the vicinity of the Defence Research Board camp (lat. 81 ${ }^{\circ} 25^{\prime}$ N., long. $76^{\circ} 50^{\prime}$ W.). The cover was composed of large pans of ice which had frozen together with little rafting. Its surface was neither as flat as first-year ice, nor was it smoothly undulating like pack ice. The ice thickness was about $2.5 \mathrm{~m}$ and the salinity slowly increased from about $\mathrm{I} \%$ near the surface to about $2 \%$ at a depth of $2 \mathrm{~m}$. When the observations began, hard packed snow covered about nine-tenths of the ice. The snow surface was partially white and about equally grey with dust wind-blown from the adjacent shore which was about $0.5 \mathrm{~km}$ away. 


\section{(b) The observations}

Incident and reflected shortwave radiation were recorded automatically every 6 min on strip chart, starting on 3 May and ending on 23 May 1967. A plot of the chart for I8 May, typical of a sunny day, is shown in Figure 7, except that the discrete closely-spaced points punched on the chart have been replaced by continuous curves. The base line was obtained by shorting the galvanometer movement once per cycle. For the day shown, the incident radiation increased from about $0.24 \mathrm{cal} \mathrm{cm}^{-2} \mathrm{~min}^{-1}$ at local midnight when the solar angle was $\approx \mathrm{I} \mathrm{I}^{\circ}$ to $0.76 \mathrm{cal} \mathrm{cm}^{-2} \mathrm{~min}^{-1}$ at local noon when the solar angle was $\approx 27^{\circ}$. The corresponding values for the reflected radiation are seen to be about 0 . I I and $0.26 \mathrm{cal} \mathrm{cm}^{-2} \mathrm{~min}^{-1}$.

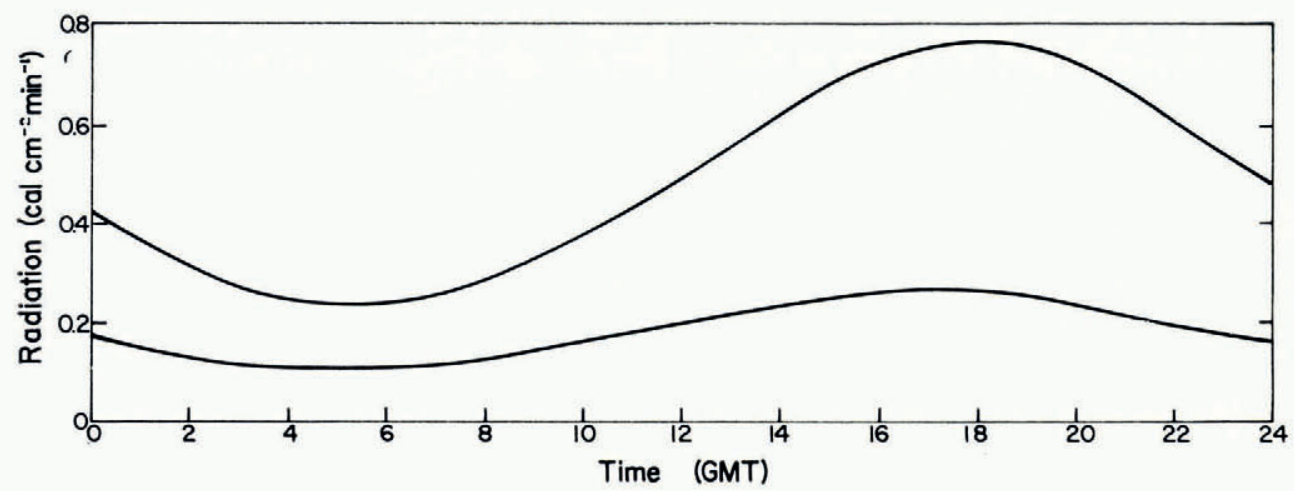

Fig. 7. A copy of the strip chart showing the incident and reflected radiation on 18 May, a sunny day. Times are in G.M.T. and millivolt readings have been converted to radiation in $\mathrm{cal} \mathrm{cm}^{-2} \mathrm{~min}^{-1}$

At the beginning of the records when the minimum solar angle was $\approx 6^{\circ}$, and for some time thereafter, the sun set behind the peaks of a mountain range for several hours each day. In clear sky conditions, the records indicated a large proportional reduction in incident or global radiation during these periods and a somewhat smaller fractional decrease in the reflected radiation, resulting in abnormally high ratios of reflected to incident radiation typically of about I 5 per cent above the expected values. A similar effect has been observed by Liljequist ( $195^{6}$ ) and can be explained in terms of changes in the spectral composition of the incident radiation and the fact that the reflectivity of a snow surface exhibits a maximum in the visible region of the spectrum. When the sun is near the horizon, the sky radiation is relatively rich in the visible region and the direct solar radiation is more rich in the red at longer wavelengths. If the direct component of the incident radiation is obscured by a mountain range, the shift in the spectrum of the global radiation is such as to produce high ratios of reflected to incident radiation. For this reason, albedo values based on observations for solar elevations of less than $10^{\circ}$ have been disregarded.

\section{(c) The results}

Incident radiation and albedo are plotted in Figure 8 as a function of time and date in G.M.T. The curves shown have been drawn through points representing values averaged over four hours. The selection of this time interval was a compromise between plotting the full 3 weeks observations on one graph, and providing sufficient detail to show any diurnal variations. The mean daily temperature, observed at normal screen height at the base camp, is also given in the same figure.

The diurnal variation of incident radiation is clearly evident in Figure 8. Irregularities in shape of the curve (e.g. 9 May) and low maximum values (e.g. 7 May) are caused by large variations in cloudiness and by heavy overcast respectively. There would also appear to be a 
diurnal variation in albedo. Careful inspection of Figure 8 shows this diurnal effect superimposed on the expected change in albedo with changes in the surface characteristics of the cover. Almost invariably, the maxima in the albedo curve correspond to minima of incident radiation. The amplitude of this diurnal variation in albedo is, with few exceptions, less than 0.025 . Whether this is a real effect, i.e. whether the reflecting properties of the cover increase with decreasing solar angle, is uncertain. It is likely that at least part of the observed diurnal variation is attributable to the response characteristics of the radiometer at small solar angle (Hinzpeter, 1952; Ambach and others, 1963).

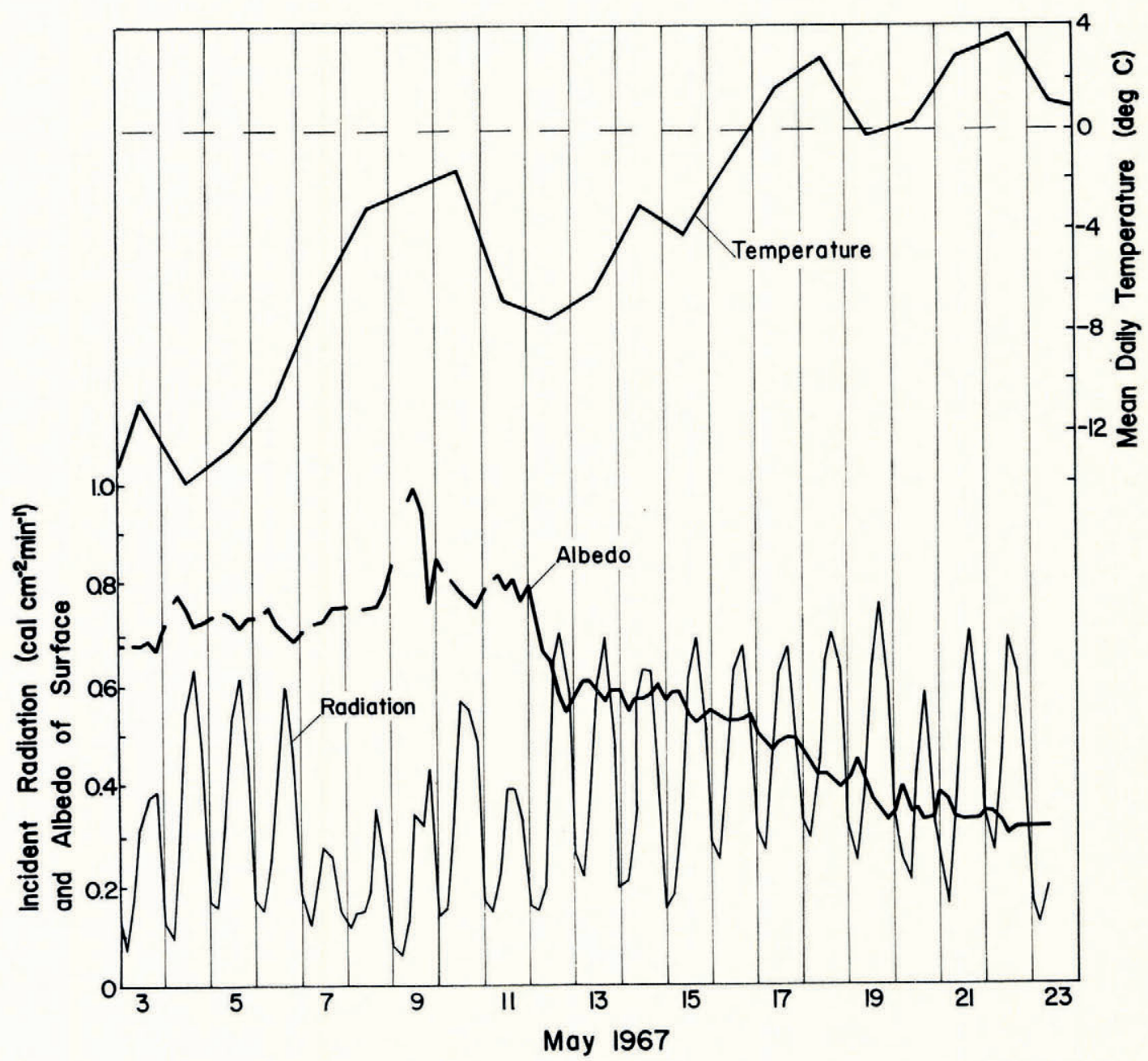

Fig. 8. Four-hourly mean values of incident radiation and albedo, and daily mean temperatures from 3 May to 23 May. Gaps in the albedo curve occur when the sun was obscured by a mountain range

In Figure 8, several marked changes in albedo are observed to occur. The increase to 0.8 on 4 May and to almost r.o starting 7 May result from fresh snowfalls, the first in trace amount left the snow cover partially transparent, and the second persisted to produce a fresh white cover. The sharp decrease in albedo on 9 May occurred because of the rapid deterioration of the snow cover when the air temperature attained a maximum value of $0.6^{\circ} \mathrm{C}$ in the 
afternoon. A further decrease on 12 May was produced by strong winds (25 knots, $12.8 \mathrm{~m} \mathrm{~s}^{-1}$ ) which cleared large patches of ice from snow. The slow decrease of albedo from about 0.6 to 0.5 between I 2 May and 17 May resulted from gradual disappearance of the remnants of snow cover and the deterioration of the surface with higher values of incident radiation. The surface remained dry until the evening of ${ }_{7} 7$ May, the first day for which the mean daily temperature (Fig. 8) exceeded the melting point. Thereafter the amount of melt water gradually increased and, by 23 May, pools of depth about $5 \mathrm{~cm}$ and of diameter around $5 \mathrm{~m}$ had developed and the albedo had decreased to a value of about 0.3 .

\section{Discussion}

The albedo of the surface of an ice cover is known to vary from point to point, particularly during the melt season when pools of melt water and dry hummocks co-exist. The use of elevated instrumentation, supported from high towers anchored to the base of the ice cover, appears to be a feasible and convenient way to measure the integrated or average albedo typical of the entire surface.

This method was used with success for a period of three weeks, extending one week into the melt season. It was observed that the average albedo, high when the ice was snow covered, decreased to less than 0.6 when the snow cover disappeared and to about 0.3 as the ice surface deteriorated and melt pools formed.

It had been planned to continue observations well into the melt season. Two assistants were left on site to inspect the installation periodically. Through lack of experience, they decided to dismantle the towers as soon as the shore lead started to develop.

\section{Acknowledgements}

It is a pleasure to acknowledge the continuing logistic support of the Defence Research Board arranged for by Dr Geoffrey Hattersley-Smith and Mr Harold Serson. The towers and instruments were assembled with the assistance of P. Stalinski and R. Stein. The towers were erected by H. Serson, assisted by J. Keys. This work was sponsored jointly by the Defence Research Board under D.D.P. Contract C.P. 69-600ooo and by the National Research Council under Grant No. A-4232.

\section{MS. received ${ }_{15}$ August 1967 and in revised form 23 November 1967}

\section{REFERENCES}

Ambach, W., and others. I963. Über die Eichung des Strahlungsbilanzmessers nach R. Schulze (Lupolengerät), [von] W. Ambach, E. Beschorner, H. [C.] Hoinkes. Archiv für Meteorologie, Geophysik und Bioklimatologie, Ser. B, Bd. 13 , Ht. 1, p. $76-95$.

Chernigovskiy, N. T. 1963. Radiatsionnyye svoystva ledyanogo pokrova tsentral'noy Arktiki [Radiational properties of the central Arctic ice cover]. Trudy Arkticheskogo $i$ Antarkticheskogo Nauchno-Issledovatel'skogo Instituta [Transactions of the Arctic and Antarctic Scientific Research Institute], Tom 253, p. 249-6o.

Fletcher, J. O. ${ }^{1965}$. The heat budget of the Arctic Basin and its relation to climate. Santa Monica, California, Rand Corporation. (Report prepared for U.S. Air Force Project Rand, R-444-PR.)

Hinzpeter, H. 1952. Bericht über neuere Arbeiten zum Solarimeter nach Gorczyński. Zeitschrift für Meteorologie, Bd. 6, Ht. 4, p. I18-21.

Langleben, M. P. 1966. On the factors affecting the rate of ablation of sea ice. Canadian Journal of Earth Sciences, Vol. 3, No. 4, p. $43 \mathrm{I}-39$.

Liljequist, G. H. 1956. Energy exchange of an Antarctic snow-field. Short-wave radiation (Maudheim $\left.71^{\circ} \mathrm{o}^{\prime} \mathrm{S}, 1^{\circ} 56^{\prime} \mathrm{W}\right)$. Norwegian-British-Swedish Antarctic Expedition, 1949-52. Scientific Results (Oslo, Norsk Polarinstitutt), Vol. 2, Part IA.

Marshunova, M. S. 1961. Osnovnyye zakonomernosti radiatsionnogo balansa podstilayushchey poverkhnosti i atmosfery $\mathrm{v}$ Arktike [Principal characteristics of the radiation balance of the underlying surface and of the atmosphere in the Arctic]. Trudy Arkticheskogo i Antarkticheskogo Nauchno-Issledovatel'skogo Instituta [Transactions of the Arctic and Antarctic Scientific Research Institute], Tom 229, p. 5-53.

Vowinckel, E., and Orvig, S. I964. Energy balance of the Arctic. I. Incoming and absorbed solar radiation at the ground in the Arctic. Archiv für Meteorologie, Geophysik und Bioklimatologie, Ser. B, Bd. 13, Ht. 3, p. 353-77. 